\title{
Cladocerans of rock pools on White Sea islands: no regional differences and inversed island biogeography
}

\section{Cladocera наскальных муж островов Белого моря: отсутствие региональных разАичий и «островная биогеография наоборот»}

\author{
Sergey M. Glagolev ${ }^{1^{*}}$, Yuri S. Bykov ${ }^{2}$ \\ С.М. Гиаголев ${ }^{1 *}$, Ю.С. Быков ${ }^{2}$
}

\footnotetext{
${ }^{1}$ Moscow South-West High School, Bakinskikh komissarov str. 3, build. 5, Moscow 119571, Russia.

${ }^{1}$ Московская Гимназия на Юго-Западе № 1543, ул. 26-ти Бакинских комиссаров, д.3, к.5, Москва 119571, Россия.

*corresponding author, e-mail: sglagolev@yandex.ru

${ }^{2}$ School of Biology, Moscow State University, Vorobyevy gory, Moscow 119899, Russia.

${ }^{2}$ Московский Государственный Университет им. М.В.Ломоносова, биологический факультет, Воробьевы горы, д. 1, Москва 119899 , Россия
}

KEY WORDS: Cladocera, rock pools, species composition, regional differences, frequencies of occurrence, White Sea, islands, Kandalaksha Gulf.

КЛЮЧЕВЫЕ СЛОВА: Cladocera, наскальные лужи, видовой состав, региональные различия, частоты встречаемости, Белое море, острова, Кандалакшский залив.

ABSTRACT. We studied the species composition and the occurrence frequency of Cladocera in rock pools of the White Sea islands (Kandalaksha Gulf). In the course of our research 13 freshwater cladoceran species were identified, with occurrence frequency for nine of them exceeding 5\%. Alonella excisa and Daphnia curvirostris were found in the White Sea rock pools for the first time. No differences in species composition were found between different archipelagos in study area. Plotted accumulation curves revealed that complete inventory of island cladoceran fauna requires sampling of 25-50 pools per island. Species richness does not correlate with either size of the island or its remoteness from the continent. It turned out that an island closest to the continent demonstrates the lowest species richness (three Cladocera species), which is consistent with data on continental pools from other studies. The reasons of such a depleted species richness are discussed.

РЕЗЮМЕ. Изучен видовой состав и частоты встречаемости Cladocera в наскальных лужах островов Кандалакшского залива Белого моря. Найдено 13 видов ветвистоусых. Частота встречаемости девяти видов превышала $5 \%$. Впервые в наскальных лужах Белого моря обнаружены Alonella excisa и Daphnia curvirostris. Между разными группами островов в районе исследований не обнаружено различий видового состава. Построенные кривые накопления говорят о том, что для полного выявления фауны ветвистоусых на острове надо взять пробы из 25-50 луж. Видовое разнообразие ветвистоусых не связано с размерами острова и с его удален- ностью от материка. Наиболее беден видовой состав на острове, примыкающем к материку (3 вида Cladocera), что соответствует данным других работ о бедности видового состава материковых луж. Обсуждаются возможные причины снижения видового разнообразия в материковых лужах.

\section{Introduction}

Rock pools attract more and more attention as model objects for various ecological studies [Srivastava et al., 2004; Brendonck et al., 2010]. Each pool is a relatively simple ecosystem with a small number of species, which allows to study interactions among species and factors affecting their dispersal, population dynamics, and genetic structure of populations on large numbers of model water bodies.

Rock pools are common for different landscapes over all the world [Brendonck et al., 2010]. Pools can significantly vary in salinity, $\mathrm{pH}$, primary production, and other abiotic factors. They are often present on the seashores and islands. The pools on a same island can be considered as a metacommunity and its residing populations as metapopulations [Haag et al., 2005]. The pools of the same island may form groups and cascades, in which case the water can flow directly from one pool into the other during the rain. The pools situated on several islands make up a more sophisticated system. Furthermore, the islands themselves vary in size and their proximity to the continent.

In many cases Cladocera turn out to be a major group constituting zooplankton of rock pools. Factors 
affecting distribution of cladocerans in rock pools were studied in details on the Baltic Sea islands [Ranta, 1979, 1982; Bengtsson, 1986, 1988, 1989; Pajunen \& Pajunen, 2003, 2007]. These works show that Daphnia species (Daphnia magna, D. pulex, D. longispina) distribution is affected by such factors as salinity, pool permanency (which in turn depends on pool depth) and interspecific competition. However, other Cladocera species were not studied in detail in these works.

Species composition of Cladocera of rock pools and some aspects of cladocerans biology were described for White Sea islands in a few articles [Ghilarov, 1967; Vekhov, 2001; Stogov et al., 1996, 2010; Polyakova et al., 2006]. Ghilarov [1967] and Vekhov [2001] used single sampling in their studies. Stogov and Polyakova with colleagues conducted long-term observations but their works do not contain data on frequency of occurrence of Cladocera species on distinct islands. That's why we decided to held long-term observations of Cladocera species composition and its dynamics in rock pools on the White Sea islands.

In 2001 we began to study rock pools on islands belonging to Keretsky Archipelago, Kem-Ludy Islands and several islands of the Kiv Bay (Kandalaksha Gulf, White Sea). The aim of our work is to study fauna of the Cladocera and to reveal patterns of their distribution among different pools and islands depending on its parameters. Particularly, we made an effort to estimate are there any differences in species composition and occurrence frequencies between different islands and groups of islands. Preliminary results of our studies in 2003-2005 were published in previous communication [Glagolev et al., 2007].

This paper represents our results of long-term observations on the Cladocera species composition and frequency of their occurrence in the studied rock pools.

\section{Materials and Methods}

\section{Long-term Observations}

We observed 54 pools in years 2003-2005, 2007, and 2008 on eight islands in the study area (Fig. 1) using the standard methods. We studied three groups of islands: 1) islands of Kem-Ludy Archipelago (island Asafiy (AY), island "Korablik" (KL), island Korzhnichikha (KR)), 2) islands of Kiv Bay (island Bolshaya Odinokaya Luda (BO), island Srednyaya Odinokaya Luda (SO), island "Grozdovnik" (GR)); $\mathrm{BO}$ and $\mathrm{SO}$ are the most remote from the continent in the study area and form a subgroup "Odinokie Ludy" 3) islands of Keretsky Archipelago (island Sidorov (SV), island "Cherepakha" (CH)). We observed most pools once a year in the end of July - beginning of August. In years 2007 and 2008 we observed pools on islands $\mathrm{GR}, \mathrm{BO}, \mathrm{SO}, \mathrm{CH}, \mathrm{SV}$ (in total 30 pools) twice (17-21.07.2007, 19-22.07.2008 and 7-9.08.2007, 810.08.2008) to find how the species composition of
Cladocera in rock pools had been changing during the short periods of time.

We marked each pool with a number painted on the rock in order to find this pool next year. We have noted presence of a lichen Xanthoria spp. on the rocks around the pool (at the distance less than $1 \mathrm{~m}$ ), which is a good indicator of frequency of the bird visits. This lichen requires large amounts of nitrogen compounds present in bird droppings [Armstrong, 1984]. We also noted the presence of other animal taxa (including potential predators) in some of pools.

We sampled cladocerans using a plankton net (mesh \#68) and identified the collected species immediately after sampling with a portable microscope. Some samples have been preserved in $96 \%$ ethanol. In doubtful cases we addressed to Cladocera taxonomy experts (see Acknowledgments).

\section{Wide-scale pool survey}

In 2007, 2008, and 2010 we sampled more pools on several islands in order to find the dependence of our results on the size of samples. In 2007 we examined islands BO (40 pools), SO (23 pools), CH (34 pools), AY (23, different from annually observed pools). In 2008 we visited only Malaya Odinokaya Luda (MO, 17 pools). This one belongs to the group of Kiv Bay islands (Fig. 1). In 2010 we examined islands BO (46 pools), SO (45 pools), and $\mathrm{CH}$ (45 pools). In 2010 we sampled 59 pools on Ivankov island(IK), situated in the Kiv Bay (Fig. 1). In 2007 and 2010 we counted total number of pools on the explored islands. The pool was defined as a water-hole with salinity less than $6 \%$, maximum depth more than $5 \mathrm{~cm}$ and maximum length more than $1 \mathrm{~m}$. On the large island AY the pools were counted only on the coastline, within $100 \mathrm{~m}$ from the shore.

On the $1^{\text {st }}$ of August 2011 we sampled 23 pools on Srednye Ludy Islands (13 pools on the large island and ten on the two small nearby islands) that are the most remote from Kandalaksha Gulf coasts and 12 pools on island Naumikha (Fig. 1).

Statistical analysis was held using the statistical environment R 2.9.0 [R Development Core Team, 2004]. We tested the statistical significance of species frequencies of occurrence differences between islands with the proportions test. Sample-based accumulation curves [Colwell et al., 2004] were plotted using EstimateS 8.2.0 [Colwell, 2006], for details see Results.

\section{Results}

The total number of pools on a single island in 2007 varied from 10 (on small island KL and rather big $\mathrm{KR})$ to 260 (AY). 50 pools were found on SO, 75 on $\mathrm{BO}, 150$ - on $\mathrm{CH}$. In 2010 the number of pools on several islands was counted after a long period of dry weather. We found 45 pools both on BO and on SO. After a rainy period in 2010 we found 324 pools on $\mathrm{CH}$, and 60 on IK. On CH 221 pools were located on 


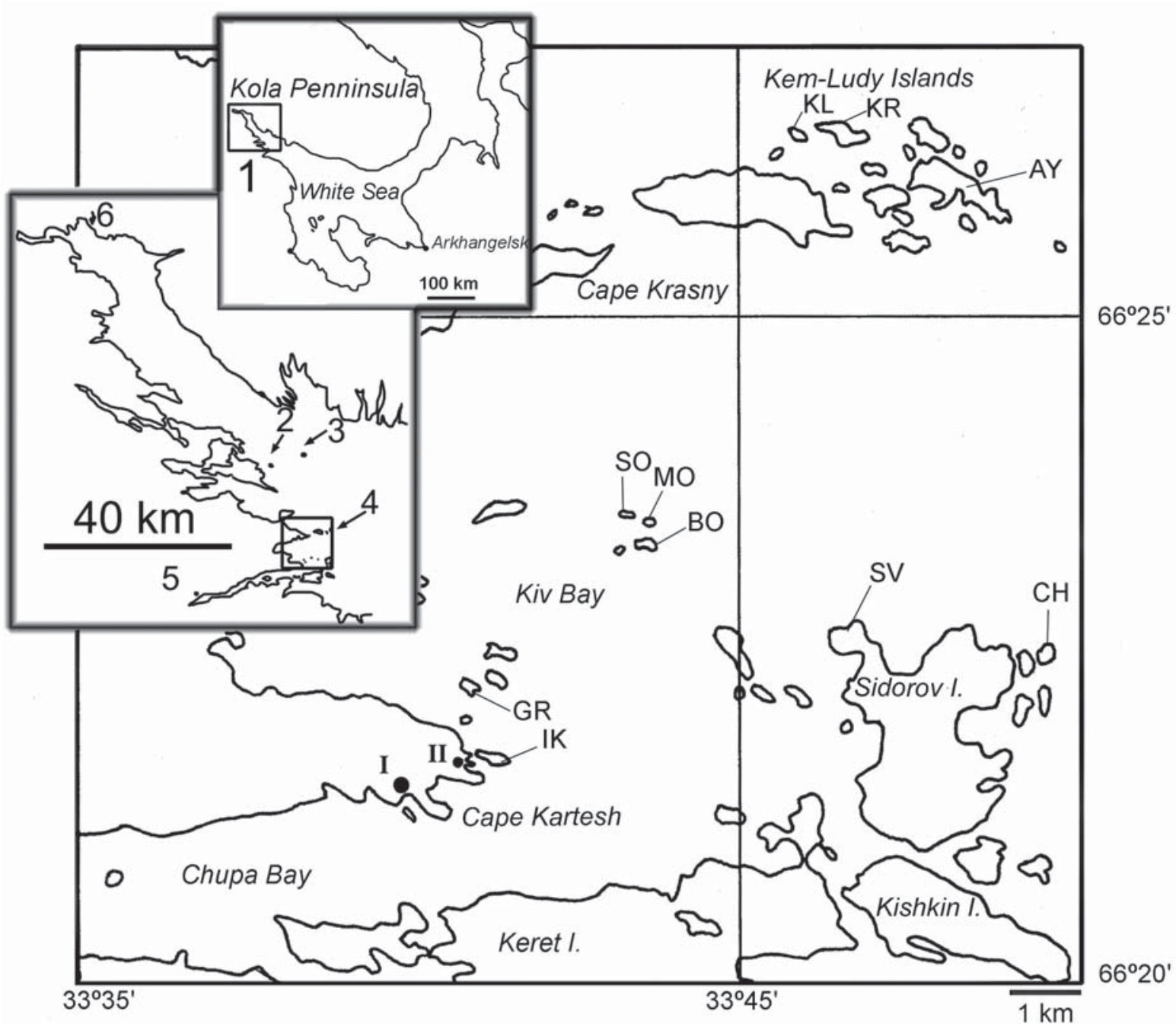

Fig. 1. Box at the top left: 1 - Study area on the map of the White Sea, 2 - the island of Naumikha, 3 - Srednie Ludy Islands, 4 main study area, 5 - Chupa, 6 - Kandalaksha. The investigated islands: BO - Bolshaya Odinokaya Luda island (N 66 $22^{\prime} 25^{\prime \prime}$, E

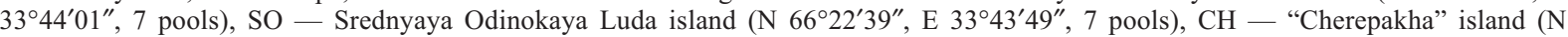

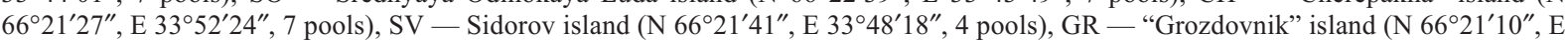
$33^{\circ} 40^{\prime} 25^{\prime \prime}, 2$ pools), IK - Ivankov island (wide-scale survey, see text), KR - Korzhnichikha island (N 66 $25^{\prime} 57^{\prime \prime}$, E $33^{\circ} 47^{\prime} 43^{\prime \prime}, 1$ pool),

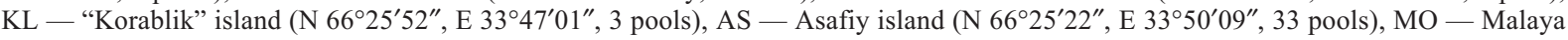
Odinokaya Luda island (wide-scale survey, see text). I — Kartesh Biological Station, II - Expedition's camp, conventional names of the nameless islands named during White Sea Expedition of Moscow South-West High School are given in quotations.

Рис. 1. На врезке: 1 - положение района исследований на карте Белого моря, 2 - о. Наумиха, 3 - Средние Луды, $4-$ расположение района исследований, 5 - Чупа, 6 - Кандалакша. Исследованные острова: ВО - о. Большая Одинокая Луда

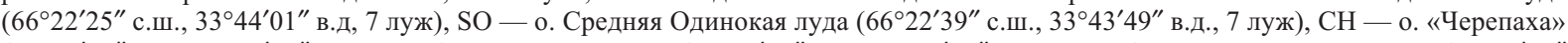

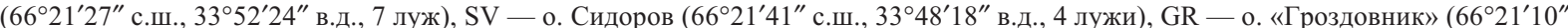

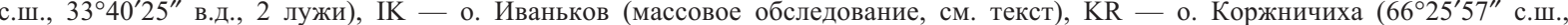

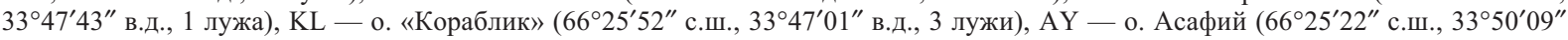
в.Д., 33 лужи), МО - о. Малая Одинокая луда (массовое обследование, см. текст). I — Биостанция ЗИН РАН «мыс Картеш» II базовый лагерь экспедиции. В кавычках даны условные названия, присвоенные безымянным островам во время беломорской экспедиции Московской гимназии № 1543.

the seaward side, and 113 on the side faced to the large $\mathrm{SV}$ island. According to our observations, this pattern of pools distribution often occurs on the islands of our study area. Most pools are disposed on the seaward side of the island which is usually more flat. The number of pools does not clearly correlate with the size of islands; it can differ a lot on the islands with approximately same size (for example, $\mathrm{CH}$, IK, and $\mathrm{BO})$.
The surface area of the observed pools varied from 0.3 to $50 \mathrm{~m}^{2}$ (average $11 \mathrm{~m}^{2}$ ), the pool depth varied from 10 to $150 \mathrm{~cm}$ (average depth $34 \mathrm{~cm}$ ) (2003-2007 data).

\section{Species Composition}

During the period of 2003-2005 12 species of Cladocera were found permanently in the study area (Table 1). 
Table 1. List of the Cladocera species observed in the rock pools of the study area. Average frequencies of occurrence are shown for the "common" species (frequency of occurrence $>5 \%$; wide-scale surveys data are included).

Таблица 1. Список видов Cladocera, найденных в наскальных лужах в районе исследований. Для «обычных» видов (средняя частота встречаемости $>5 \%$ ) приведены средние частоты встречаемости. Включены данные массовых обследований.

\begin{tabular}{|c|c|c|}
\hline & Species & 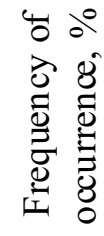 \\
\hline $\begin{array}{l}1 . \\
2 . \\
3 . \\
4 . \\
5 . \\
6 . \\
7 . \\
8 . \\
9 . \\
10 . \\
11 . \\
12 . \\
13 .\end{array}$ & $\begin{array}{l}\text { Acantholeberis curvirostris (O.F.Müller, 1776) } \\
\text { Alonella excisa (Fischer, 1854) } \\
\text { Bosmina longirostris (O.F.Müller, 1785) } \\
\text { Ceriodaphnia quadrangula (O.F.Müller, 1785) } \\
\text { C.pulchella Sars, } 1862 \\
\text { Chydorus sphaericus (O.F.Müller, 1785) } \\
\text { Daphnia curvirostris Eylman, 1887, emend. Johnson, } 1952 \\
\text { Daphnia longispina O.F. Müller, 1785 } \\
\text { Daphnia pulex Leydig, } 1860 \\
\text { Daphnia magna Straus, } 1820 \\
\text { Macrothrix hirsuticornis Norman et Brady, } 1867 \\
\text { Polyphemus pediculus (L., 1758) } \\
\text { Scaphleberis mucronata (O.F.Müller, 1776) }\end{array}$ & $\begin{array}{c}67 \\
10 \\
6 \\
14 \\
51\end{array}$ \\
\hline & Pools sampled & 592 \\
\hline
\end{tabular}

Table 2. Average frequencies of occurrence of "common" Cladocera species: average for all study area for each year of study and average for all years of study for each group of islands.

Таблица 2. Частоты встречаемости «обычных» видов Cladocera: средние для всего района исследований по каждому году наблюдений и средние по каждой группе островов за весь период наблюдений.

\begin{tabular}{|c|c|c|c|c|c|c|c|c|c|}
\hline & \multirow[b]{2}{*}{2003} & \multirow[b]{2}{*}{2004} & \multirow[b]{2}{*}{2005} & \multirow[b]{2}{*}{2007} & \multirow[b]{2}{*}{2008} & \multicolumn{4}{|c|}{ Average for all years } \\
\hline & & & & & & $\begin{array}{l}0 \\
\infty \\
0 \\
0\end{array}$ & $\begin{array}{l}\text { I } \\
+ \\
+ \\
\text { is }\end{array}$ & 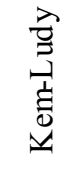 & 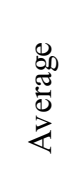 \\
\hline Daphnia magna & 44 & 48 & 46 & 41 & 40 & 62 & 14 & 49 & 44 \\
\hline D.pulex & 18 & 11 & 26 & 17 & 21 & 41 & 8 & 10 & 19 \\
\hline D.longispina & 11 & 11 & 2 & 10 & 8 & 1 & 15 & 10 & 9 \\
\hline D.curvirostris & 6 & 4 & 9 & 8 & 7 & 7 & 4 & 8 & 7 \\
\hline Scapholeberis mucronata & 20 & 26 & 18 & 39 & 35 & 27 & 55 & 17 & 29 \\
\hline Ceriodaphnia sp. & 20 & 39 & 31 & 39 & 39 & 51 & 39 & 21 & 34 \\
\hline Polyphemus pediculus & 15 & 9 & 7 & 18 & 23 & 1 & 24 & 21 & 15 \\
\hline Bosmina longirostris & 22 & 20 & 15 & 26 & 25 & 1 & 52 & 21 & 22 \\
\hline Chydorus sphaericus & 57 & 48 & 50 & 70 & 60 & 78 & 59 & 47 & 58 \\
\hline Pools sampled & 54 & 54 & 54 & 77 & 75 & 96 & 77 & 135 & 314 \\
\hline
\end{tabular}




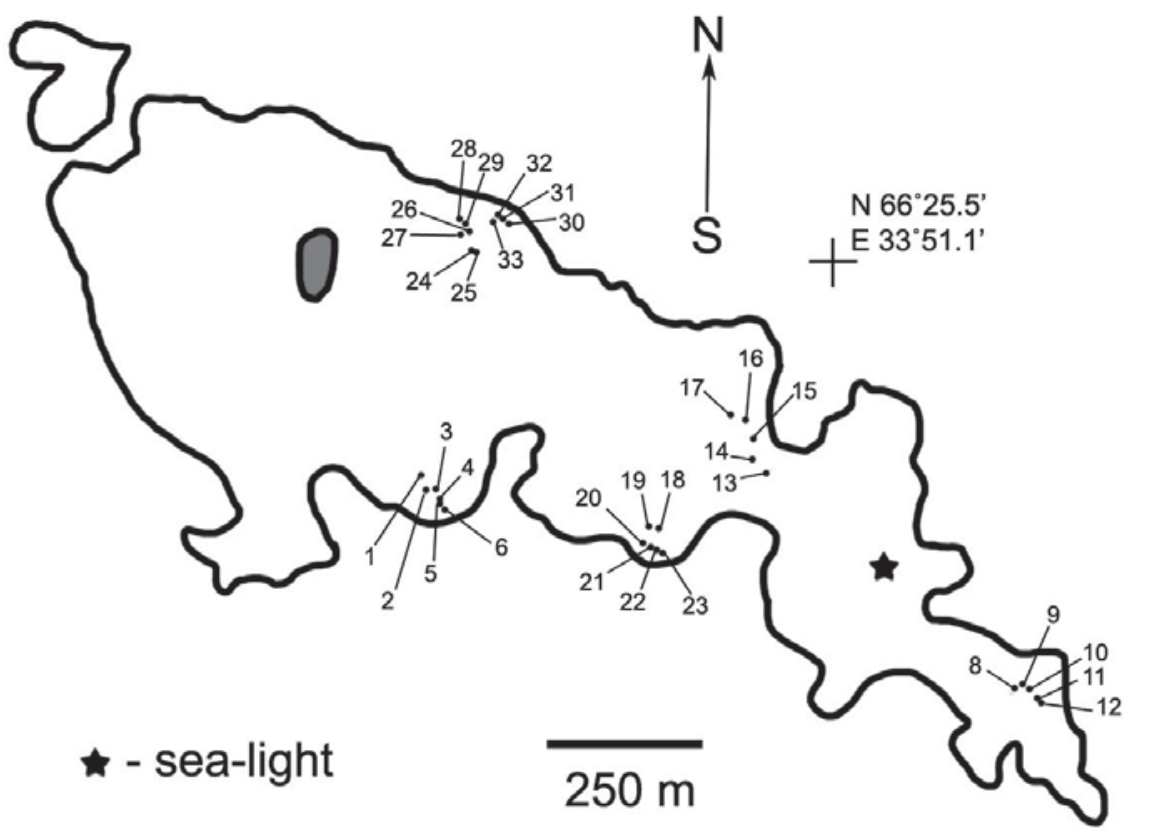

Fig. 2. Pools on AY (KemLudy Islands) can be grouped according to their position. Inner lake is shown in gray.

Рис. 2. Группы луж на о. Асафий (архипелаг Кемь-Луды). Серым показано внутреннее озеро.
As for the episodically occurring species, Alonella excisa was once found in the samples collected in 2001 on SV island, and never observed anymore. However, on AY we have recorded at once an unidentified Chydoridae species which was different from Chydorus sphaericus. We found Ceriodaphnia pulchella in 2003 samples from two islands - $\mathrm{CH}$ and SV. In further studies both Ceriodaphnia species were noted as Ceriodaphnia spp. due to the difficulties of species identification in the field. Finally, according to samples analyzed in the laboratory, most pools were inhabited by $C$. quadrangula.

We found all of the nine "common" species at least once in all groups of islands during the whole period of observations. However, several "common" species were found episodically in certain groups of islands. For example, Daphnia longispina was observed at "Odinokie Ludy" subgroup only once during the entire period of studies and only on BO in a single pool. We noted Polyphemus pediculus in this subgroup only twice: in 2008 and 2010 only on SO. Bosmina longirostris was found there in 2003 (on BO) and in 2010 (on SO). In 2003-2005 D. curvirostris was not found on these islands, while in 2007, 2008, and 2010 we found it on both of the islands. Not only did we notice the fact of episodic occurrence of certain species on several islands, but also noted the episodic absence. For example, in 2010 during the complete sampling on $\mathrm{CH}$ we did not find some species which regularly occured on this island - Polyphemus pediculus, Daphnia curvirostris, and $D$. pulex.

The species composition on island AY did not change during the study period.

Only three species of Cladocera were found on IK: D. magna, C. sphaericus, and Scapholeberis mucronata.
In 2011 during the single sampling of pools on the Srednie Ludy Islands and island Naumikha five species of Cladocera were found on both islands: Daphnia magna, D. curvirostris, Chydorus sphaericus, $S$. mucronata, and Ceriodaphnia sp. (all of them except for D. curvirostris with maximal occurrence frequencies, see Table 1).

\section{Frequencies of Occurrence}

For each "common" species we have calculated average frequency of occurrence (the percentage of pools occupied by the given species) for all years of observation in the study area (Table 1). The most common (frequency $>50 \%$ ) species are Daphnia magna and Chydorus sphaericus. Ceriodaphnia spp. and Scapholeberis mucronata were found a bit less often than previous species (20-30\%). Less common species are D. pulex, Bosmina longirostris, and D. curvirostris (10-20\%). The rarest of the "common" species are D. longispina and Polyphemus pediculus $(<10 \%)$.

Average frequencies of occurrence of the Cladocera species in the study area varied during the period of our studies (Table 2). It differed no more then in 1.5-2 times for most species. Polyphemus pediculus frequency was the most variable one: it ranged from 7 to $23 \%$ with the mean value of $15 \%$ (not taking into account the wide-scale surveys data).

According to the observations of 54 pools on eight islands in 2003-2005, 2007, 2008 and the wide-scale survey of 278 pools on five islands in 2007 and 2010 we calculated frequencies of occurrence on different islands and islands groups (Table 2, and Appendix Tables 1, 2).

In spite of the previously published data on annually observed pools [Glagolev et al., 2007], we have found 
statistically significant differences between the islands in the occurrence frequencies of Cladocera during the wide-scale sampling (Appendix Table 3).

\section{Groups of Pools}

We sampled 33 pools on island AY (Kem-Ludy Islands) annually. They can be divided into seven groups according to their position on the island (Fig. 2, Appendix Table 4). In the most cases the distance between the groups was more than $200 \mathrm{~m}$ and the distance between two neighboring pools in one group was no more than $30 \mathrm{~m}$. Only two groups of pools (out of seven groups sampled) were inhabited by all species found on the island during the five years of observations (Appendix Table 4).

Other five groups of pools lacked some species of Cladocera. For example, frequently found species Daphnia magna and D. pulex never occurred in the pools 1-6. Bosmina longirostris, Polyphemus pediculus, and Ceriodaphnia never occurred in the pools 8-12. Finally, all species found on the island never occurred in a single group in particular year.

We have plotted accumulation curves [Gotelli \& Colwell, 2001] for the data obtained by different approaches to island sampling on AY and BO. The curves plotted for the most complete sampling (Fig. 3) show that the full description of cladoceran fauna of the island rock pools requires sampling of $25-50$ pools per island. Of course, one should try to choose pools with different conditions for sampling (for example, more alkaline and saline pools located close to seashore and also more acidified and non-mineralised pools more distant from the sea).

\section{Discussion}

\section{Species composition}

A.M. Ghilarov [1967] was one of the first to investigate zooplankton of rock pools in the Kandalaksha Gulf of the White Sea. He studied 36 rock pools (both freshwater and brackish) on islands Kastyan, Naumikha, Asafiy, and Krasny (the last two islands belong to the Kem-Ludy Islands) and found nine species of Cladocera. He also determined their frequencies of occurrence and common occupancy. Unfortunately, this work does not contain any data on distribution of the studied pools on the islands. Vekhov [Vekhov, 2001] studied crustaceans of the rock pools of Kandalaksha Gulf taking a single sample from each pool on 23 islands including Kemludsky, Vorotikha, and Krasny belonging to Kem-Ludy Islands, and Gorely belonging to Keretsky Islands. He found 14 Cladocera species in 250 sampled pools including two purely marine species - Podon intermedius Lilljeborg, 1853 (which is more likely to be Podon leuckarti G.O. Sars, 1862 [Mordukhay-Boltovskoy \& Rivier, 1987]) and Evadne anonyx G.O. Sars, 1897 (actually — Evadne
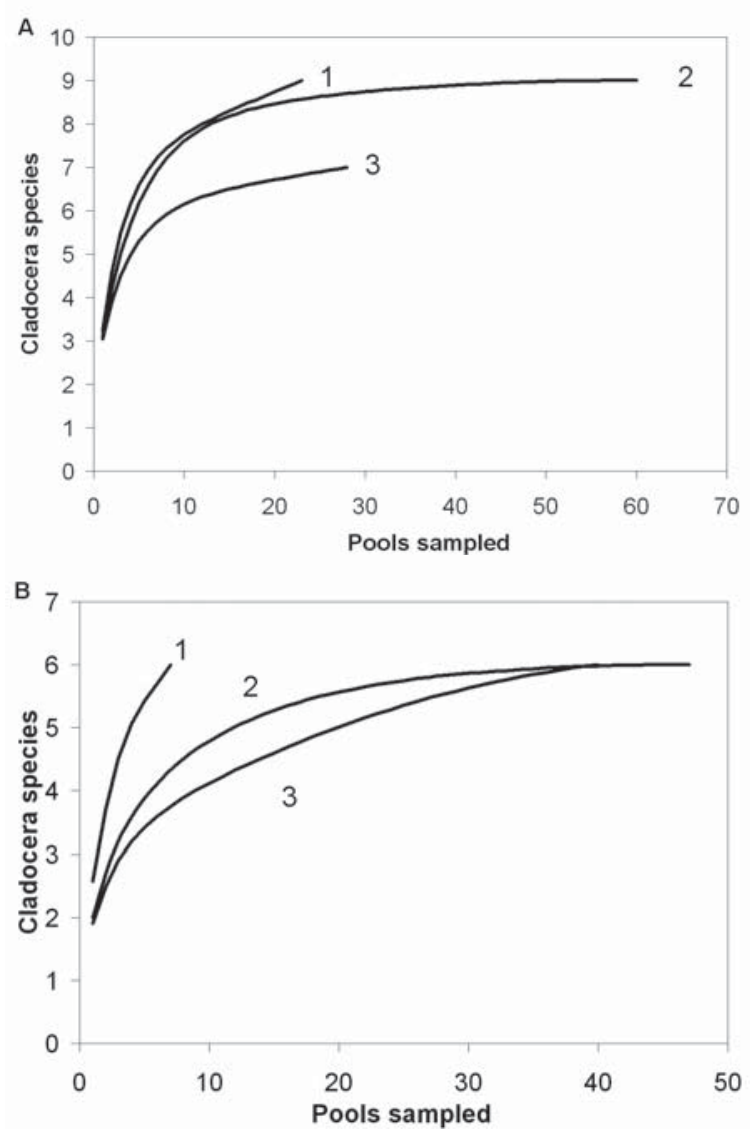

Fig. 3. A relationship between species number revealed and the number of pools sampled on an island (the data for 2007) $\grave{A}$ - AS island: 1 annually visited pools, 2 - annually visited pools + wide-scale survey, 3 - wide-scale survey, B - BO island: 1 annually visited pools, 2 - annually visited pools + wide-scale survey, 3 - wide-scale survey.

Рис. 3. Зависимость количества видов на острове от количества обследованных луж (построены по данным 2007 г) А о. Асафий. 1 - ежегодно обследуемые лужи, включаемые в выборку, 2 - ежегодно обследуемые лужи + дополнительно обследованные, 3 - дополнительно обследованные лужи. В о. Большая Одинокая Луда. 1 - ежегодно обследуемые лужи, 2 - ежегодно обследуемые лужи + дополнительно обследованные, 3 - дополнительно обследованные лужи.

nordmanni Lovén, 1836 [Mordukhay-Boltovskoy \& Rivier, 1987]). Another study of cladoceran fauna of Kandalaksha Gulf islands was conducted by Stogov [Stogov et al., 1996, 2010] and Polyakova [Polyakova et al., 2006]. They found 13 species of Cladocera on islands of Keretsky Archipelago (Fig. 1).

Ghilarov [Ghilarov, 1967] and Polyakova [Polyakova et al., 2006] noted other Cladocera species in the same study area: Bosmina obtusirostris G.O. Sars, 1862, Daphnia arctica Werestschagin, 1913 and Ceriodaphnia affinis Lilljeborg, 1900. Presence of these species in the rock pools was not confirmed in our research.

Daphnia arctica is probably a junior synonym of Daphnia lacustris G.O. Sars, 1862 [Glagolev, unpubl.; Nilssen et al., 2007]. Daphnia lacustris was not found 
in our study; however certain islands are inhabited by D. longispina morphotypes resembling this species [Tsarev et al., 2011]. We suppose this species was misidentified in the work of Polyakova et al. [2006] and Ghilarov [1967] where the old taxonomy had been used. Acantholeberis curvirostris was found each year in a single pool on the top of island $\mathrm{CH}$ which resembles sphagnum bog - a typical habitat of this species [Fryer, 1980]. That's why we suppose that regarding this species as typical for rock pools [Polyakova et al., 2006] is not sufficiently justified. Alonella excisà and Macrothrix hirsuticornis also occur rarely in the rock pools.

Stogov [Stogov et al., 1996] regard Alonella nana (Baird, 1850) as a typical rock pools species. We have not found this species on the islands studied in the same region. We suppose our sampling method could to be blamed in missing this species or it may persist in the pools only in the restricted season, for example, in spring.

The systematics of Ceriodaphnia was not revised, and species identification is provisional. That's why it is difficult to say whether Ceriodaphnia affinis noted by Vekhov [Vekhov, 2001] is the same species with $C$. quadrangula found in our research or a separate species. Species composition of Ceriodaphnia in the White Sea rock pools requires an additional study.

Stogov [Stogov et al., 1996] mentioned the presence of Daphnia cristata G.O. Sars, 1862, Diaphanosoma brachyurum (Lievin, 1848) and Holopedium gibberum Zaddach, 1855 in the White Sea rock pools. Such dramatic differences in species composition on similar islands seems unlikely to us. Furthermore, $D$. cristata and $H$. gibberum are typical lake species which practically never occur in temporary ponds. We have not found these species and consequently their presence in the rock pools requires confirmation. However, recent report by Stogov et al. [2010] is more consistent with our data.

Simocephalus vetulus (O.F. Müller, 1776) is another species observed previously by Vekhov [Vekhov, 2001] on the Kandalaksha Gulf islands which was not found during our study. This species was found by Vekhov on two islands in the northern part of Kandalaksha Gulf and on Kastyan island lying out of our study area. Ceriodaphnia rotunda G.O. Sars, 1862 was found by Vekhov on five islands including two belonging to Kem-Ludy islands, but not studied in our work. The species is noted as rare. At the same time Vekhov [2001] did not note on Kem-Ludy Islands Polyphemus pediculus which is quite common there.

We found Alonella excisa and Daphnia curvirostris for the first time on the White Sea islands. The last species is probably recorded for the first time ever in all White Sea region [Glagolev, 1986], although it is quite abundant in rock pools. Daphnia curvirostris was missed in previous studies of rock pools fauna because this species distantly resembles $D$. pulex; although in reality it can be easily distinguished from the later (Fig. 4). This could have lead to distortion of faunistic and ecological data. Presence of these easily distinguish-

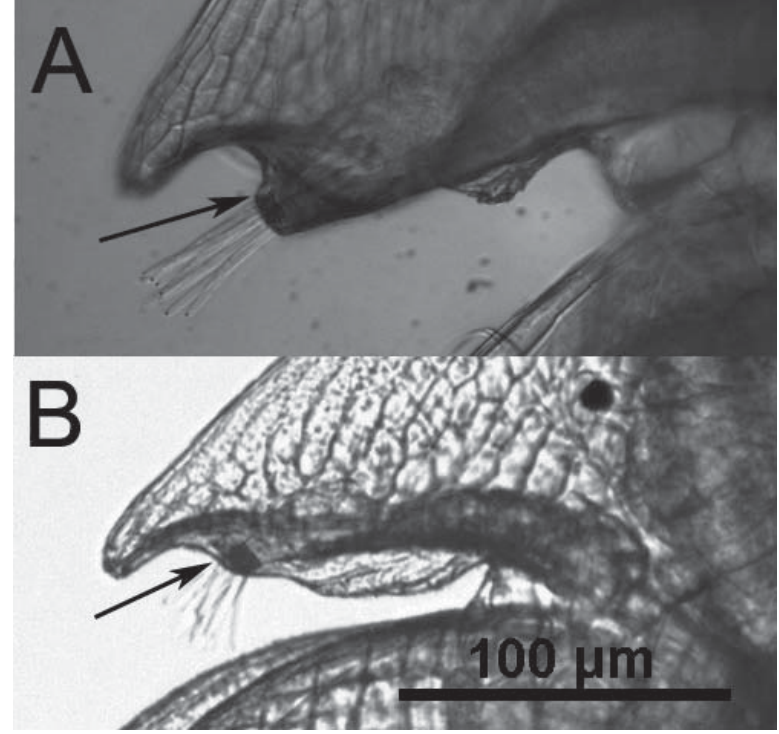

Fig. 4. The main diagnostic difference of Daphnia pulex and D. curvirostris females, A - rostrum and antennulae of D. pulex, antennula base (arrow) is not reduced, B - rostrum and antennulae of $D$. curvirostris, base of antennula (arrow) is reduced.

Рис. 4. Морфологические отличия Daphnia pulex и D. curvirostris. A - рострум D. pulex, основание антеннул (отмечено стрелкой) не редуцировано, В - рострум D. curvirostris, основание антеннул (отмечено стрелкой) редуцировано.

able species [Glagolev, 1995] should be taken into account in further investigations of rock pools zooplankton communities.

According to our data and previous records, three groups of Cladocera species can be distinguished on the islands of Kandalaksha Gulf: 1) Alonella excisa, Macrothrix hirsuticornis, and Acantholeberis curvirostris are rarely found on the islands although being typical for continental lakes and bogs; 2) Polyphemus pediculus, Daphnia longispina, Bosmina longirostris, Scapholeberis mucronata, Simocephalus vetulus, Chydorus sphaericus (and probably Ceriodapnia pulchella) occur both in the rock pools and continental lakes; 3) Daphnia magna, D. curvirostris, D. pulex, and Ceriodaphnia quadrangula inhabit only rock pools in our study area.

We have not found differences in fauna composition between different groups of islands described in previous works [Vekhov, 2001]. We suppose this discrepancy to be explained by the small number of the observed pools per one point and lack of statistical processing of the data in Vekhov's work. Apparently the distance of $2-3 \mathrm{~km}$ between islands does not seriously interrupt cladocerans dispersion and most islands have suitable habitats for all these species. Daphnids are found to have particularly high dispersal ability [Louette \& De Meester, 2005].

We have found five species of Cladocera on Srednie Ludy which is the most isolated group of islands (Fig 1) and on Naumikha island, although Vekhov [2001] notes only three species on Srednie Ludy and eight on Naumikha. It is possible that, as well as on $\mathrm{BO}$ and $\mathrm{SO}$, 
repeated sampling of more pools on Srednie Ludy Islands and Naumikha island can help to find other species of Cladocera on these islands. However, the absence of Simocephalus vetulus on all islands explored in our study area can indicate that certain qualitative regional differences of cladoceran fauna exist in different regions of Kandalaksha Gulf.

Polyphemus pediculus could have immigrated to BO and SO in 2008 and fixed there until 2010. Similar situation is shown for $D$. curvirostris. To confirm a hypothesis that certain species may appear on one island and disappear on the other in a decade, one needs to make annual sampling of all pools on the island and probably to study also the bank of resting eggs.

Samples number sufficient to reveal species composition on an island

The investigation of rock pools fauna could be compared with investigation of the lake fauna. It was shown that complete detection of zooplankton fauna of a lake requires 25-50 samples from different biotopes [Dumont \& Segers, 1996]. Investigation of pools fauna on a single island requires sampling of 25-50 pools representing different biotopes of island metacommunity; it is confirmed by the accumulation curves (Fig. 3).

Vekhov [2001] sampled on average 10 pools per island and this could result in incomplete uncovering of species composition and frequencies of occurrence of Cladocera species on different islands. It is especially feasible if only one group of pools is sampled (see Appendix Table 4).

\section{Frequencies of Occurrence}

$\mathrm{BO}$ and $\mathrm{SO}, \mathrm{SO}$ and $\mathrm{AY}, \mathrm{BO}$ and $\mathrm{CH}$ show the most significant difference from each other according to the number of species with statistically different frequencies of occurrence (Appendix Table 3). This data shows that the extent of difference does not depend neither on size of islands nor on the distance between them.

\section{Depleted species number on IK island}

The most depleted is the Cladocera species composition of IK island, which is connected to the continent during low tide, but nevertheless is quite close to other islands, lying seaward. Only three species were noted on IK, and Daphnia magna was found in a single pool of 37 sampled in 2010. According to Vekhov [2001] low species richness is typical for continent coastline pools, which were sampled at four distinct points during his work. Only four Cladocera species were noted there: D. magna, D. pulex, Chydorus sphaericus and Bosmina longirostris. That's why we can assume that a small number of Cladocera species is a feature of continental coastline rock pools.

IK area size is comparable to that of $\mathrm{CH}$ and $\mathrm{BO}$. According to our data total number of pools on this island is slightly less than on BO and SO. How can such poor species composition be explained? Although this island was visited in 2010 after a long period of draught followed by heavy rains, lack of Cladocera in half of sampled pools was not caused by pools desiccation because mature Chironomidae larvae were present in many pools indicating that pools had not fully dried out. Nevertheless pools desiccation can play a certain role. Even after a rainy period practically all pools on IK were less then $30 \mathrm{~cm}$ deep, and on other islands some pools deeper them $30 \mathrm{~cm}$ were present. We can assume that pools desiccation frequency is higher on this island. It was shown [Altermatt et al., 2009] that desiccation frequency predicted from the morphometrical parameters of the pools was negatively correlated with the annual presence of three Daphnia species in rock pools. Frequent desiccation of the pools can be one of the factors contributing to the low species richness of IK pools. But this factor alone is unlikely to explain an absence of certain species, which had sufficient frequencies of occurrence on other islands in pools of the same depth.

Total number of pools on island can also influence species composition in a certain way. The number of pools estimated on IK is smaller then on comparable $\mathrm{CH}$ at the same period, and is similar to the number of pools on SO. Cladocera species richness is high on $\mathrm{CH}$, lower on SO and the lowest on IK (Appendix, Table 1). Small number of pools on the island results in increase of average distance between pools and decreased rate of the Cladocera species interchange between pools. This probably leads to increased probability of species extinction; previously it was supposed that this factor can decrease water beetles species richness [Ranta, 1982].

The neighboring continental lakes and ponds are inhabited by such species as Daphnia longispina, Polyphemus pediculus, Scaphleberis mucronata, Bosmina longirostris, and Chydorus sphaericus [Kulikova, 2001], but other rock pools "common" species are apparently absent in these water bodies. Nevertheless, IK fauna lacks both "continental" and practically all "island" cladocerans.

We can suggest that birds rarely visit island IK (during the low tide this island is connected to the continent and seabirds practically do not nest there). Absence of the lichen Xanthoria spp. on this island is a sign of rare bird visits. We can suggest that it decreases frequency of ephippia dispersal from neighboring islands and continental ponds. However, relative roles played by wind, water and birds in Cladocera dispersal among islands have not been studied yet; probably wind plays more important role then birds [Bohonak \& Jenkins, 2003].

Birds can also influence Cladocera species distribution in another way. Bird droppings enrich soil and water with nutrients causing pools eutrophication and increase of primary production. Even in large lakes bird droppings can serve as a major source of phosphorous which content often limits primary production 
[Manny et al., 1994]. It is known that Daphnia magna prefers such habitats enriched with nutrients [Koivisto, 1995]. In addition an increase of food content may decrease interspecific competition and increase Cladocera species richness. Finally, in pools rich with nutrients cladocerans can gain higher number and leave more resting eggs. It may result in increase of cladocerans survival probability and dispersal efficiency.

Probably, the main factor affecting low species richness of "continental pools" is their low diversity: small depth, lack of pools enriched with biogenic elements, etc. Testing this hypothesis requires additional observations and field experiments including artificial enrichment of pools with biogenic elements and transfer of cladocerans to these pools.

The most spectacular feature of rock pools cladoceran fauna poorly discussed in the literature is practically complete absence of Chydoridae species. Fryer [Fryer, 1985] notes that number of Chydoridae species has the strongest dependence on pond size; small ponds are inhabited by much smaller number of chydorids then the large ones. The cause of this correlation remains unknown. It was assumed that this effect is somehow connected with the diversity of water plants and specificity of chydorids' ephippia lying (many species place them on plants). It may be also partly explained by sampling techniques [J.P. Nilssen, pers.com.]. But these hypotheses remains speculative and this interesting fact requires further investigation.

\section{Concluding remark}

Our data shows that both Cladocera species richness on certain islands and the extent of difference of the species composition on different islands do not depend on the island size or their distance from each other and from the continent as predicted by classical theory of island biogeography [MacArthur \& Wilson, 1967]. The most dramatic illustration of this statement is a low species richness of continental coast pools or of the pools on IK island connected to the continent. We propose that equilibrium models can not agree with the real species composition in the first instance because of the high dispersal capabilities of Cladocera which allow them to colonize all islands with high frequencies without any respect to the islands size and distance between them.

ACKNOWLEDGMENTS. We are grateful to Nikolay N. Smirnov who confirmed Chidoridae species identification, Nikolay M. Korovchinsky for confirmation of Ceriodaphnia species identification and Aleksey A. Kotov who helped with identification of Bosmina species. Part of the material was sampled on the territory of Kandalaksha Natural Reserve. We would like to thank Reserve administration and especially Aleksandr S. Koryakin. All samplings were made during the White Sea Expedition of Moscow South-West High School (\# 1543). We thank Vladimir Ya. Berger, all members of Expedition and particularly Andrey N. Kvashenko, Nikolay
P. Datskevich, Sergey V. Sukhov for technical assistance, Ekaterina V. Eliseeva, Pyotr N. Petrov, Pyotr Datskevich, Daniil Berezhnoy, Ilya Fedorov, Olga Zlobovskaya, Sonya Kasatskaya, Vladimir Chava, Ivan Yurfyakov, Sergey Ivanov, Daria Zakrasina, Aleksey Glagolev, Polina Borisova, Mikhail Bizin, Ilya Flyamer, Aleksandra Kirichenko for their help in material collection and processing and Polina A. Volkova, Eugeny P. Altshuler, Aleksey B. Shipunov for their assistance on statistical processing and valuable advice and Anna V. Arsenieva for help with the manuscript revising. We are most grateful to Dr. J.P. Nilssen for his help with English translation and helpful advises. The work was partly funded by "Dinastia" foundation grant \# P11-018 and by Moscow institute of Open Education.

\section{References}

Altermatt F., Pajunen V.I., Ebert D. 2009. Desiccation of rock pool habitats and its influence on population persistence in a Daphnia metacommunity // PLoS ONE 4. e4703. doi:10.1371/ journal.pone.0004703

Armstrong R.A. 1984. The influence of bird droppings and uric acid on the radial growth of five species of saxicolous lichens // Environmental and Experimental Botany. Vol.24. P.95-99.

Bengtsson J. 1986. Life histories and interspecific competition between three Daphnia species in rockpools // Journal of Animal Ecology. Vol.55. P.641-655.

Bengtsson J. 1988. Life histories, interspecific competition and regional distribution of three rockpool Daphnia species // Acta univ. upsal. Compr. summ. Uppsala Diss. Fac. Sci. Vol.142. P.1-32.

Bengtsson J. 1989. Interspecific competition increases local extinction rate in a metapopulation system // Nature. Vol.340. P.713-715.

Brendonck L., Jocque M., Hulsmans A., Vanschoenwinkel B. 2010. Pools 'on the rocks': freshwater rock pools as model system in ecological and evolutionary research // Limnetica. Vol.21. P.25-40

Bohonak A.J., Jenkins D.G. 2003. Ecological and evolutionary significance of dispersal by freshwater invertebrates // Ecology Letters. Vol.6. P.783-796.

Colwell R.K., Mao C.X., Chang J. 2004. Interpolating, extrapolating, and comparing incidence-based species accumulation curves // Ecology. Vol.85. P.2717-2727.

Colwell R.K. 2006. EstimateS: Statistical estimation of species richness and shared species from samples. Version $8 / /$ Electronic resource. URL: purl.oclc.org/estimates.

Dumont H.J., Segers H. 1996. Estimating lacustrine zooplankton species richness and complementarity // Hydrobiologia. Vol.341. P.125-132.

Fryer G. 1980. Acidity and species diversity in freshwater crustacean faunas // Freshwater Biology. Vol.10. P.41-45.

Fryer G. 1985. Crustacean diversity in relation to the size of water bodies: some facts and problems // Freshwater Biology. Vol.15. P.347-361.

Ghilarov A.M. 1967. The zooplankton of arctic rock pools // Oikos. Vol.18. P.83-85

Glagolev S.M. 1986. [Morphology, systematics and geographic distribution of the cladoceran genus Daphnia from Eurasia]. PhD Thesis. Moscow: IEMEZh AN SSSR. [In Russian]

Glagolev S.M. 1995. [Genus Daphnia] // Tsalolikhin S.J. (ed.). Opredelitel' presnovodnykh bespozvonochnykh Rossii i prilezhashchikh stran. Saint-Petersburg: ZIN RAN. Vol.2. Crustacea. P.45-58 [in Russian]

Glagolev S.M., Bykov Yu.S., Datskevich P.N., Zlobovskaya O.A., Chava V.A. 2007. [Species composition and distribution of Cladocera in rock pools of White Sea islands] // Cladocera: sistematika i biologiya. Materialy Vserossiyskoy Shkoly-Kon- 
ferentsii. 8-12 Octyabrya 2007, Institut Biologii Vnutrennikh Vod, Borok, Rossiya. Nizhniy Novgorod: Vektor TiS. P.223228 [in Russian].

Gotelli N.J., Colwell R.K. 2001. Quantifying biodiversity: procedures and pitfalls in the measurment and comparison of species richness // Ecology letters. Vol.4. P.379-391.

Haag C.R., Riek M., Hottinger J.W., Pajunen V.I., Ebert D. 2005. Genetic diversity and genetic differentiation in Daphnia metapopulations with subpopulations of known age // Genetics. Vol.170. P.1809-1820.

Koivisto S. 1995. Is Daphnia magna an ecologically representative zooplankton species in toxicity tests? // Environmental Pollution. Vol.90. P.263-267.

Kulikova T.P. 2001. [Zooplankton species composition of republic Karelia inland water bodies] // Trudy KarNTRAN. Biogeogaphia Karelii. Vol.2. P.133-157 [in Russian].

Louette G., De Meester L. 2005. High dispersal capacity of cladoceran zooplankton in newly founded communities // Ecology. Vol.86. P.353-359.

MacArthur R.H., Wilson E.O. 1967. The Theory of Island Biogeography. N.J.: Princeton University Press.

Manny B.A., Johnson W.C., Wetzel R.G. 1994. Nutrient additions by waterfowl to lakes and reservoirs: predicting their effects on productivity and quality // Hydrobiologia. Vol.279/280. P.133147.

Mordukhay-Boltovskoy P.D., Rivier I.K. 1987. [Predatory cladocerans Podonidae, Polyphemidae, Cercopagidae and Leptodoridae of the world fauna]. Leningrad: Nauka Publ. [in Russian]

Nilssen J.P., Hobaek A., Petrusek A., Skage M. 2007. Restoring Daphnia lacustris G.O. Sars, 1862 (Crustacea, Anomopoda) - a cryptic species in the Daphnia longispina group // Hydrobiologia. Vol.594. P.5-17.

Pajunen V.I., Pajunen I. 2003. Long-term dynamics in rock pool Daphnia metapopulations // Ecography. Vol.26. P.731-738.

Pajunen V.I., Pajunen I. 2007. Habitat characteristics contributing to local occupancy and habitat use in rock pool Daphnia metapopulations // Hydrobiologia. Vol.592. P.291-302.

Polyakova N.V., Starkov I.A., Kosheleva A.N., Sukhikh N.M. 2006. [Rock pools zooplankton of Keretsky Islands of Kandalaksha
Gulf (White Sea)] // Materialy X Nauchnoy Konferentsii BBS im. Pertsova. Moscow. P.78-80 [in Russian].

R Development Core Team. 2004. R: A language and environment for statistical computing. Vienna: R Foundation for Statistical Computing. Electronic resource. URL: http: // www. $\mathrm{R}$ project.org

Ranta E. 1979. Niche of Daphnia species in rock pools // Arch. Hydrobiol. Vol.87. P.205-223.

Ranta E. 1982. Animal communities in rock pools // Ann. Zool. Fennici. Vol.19. P.337-347.

Srivastava D.S., Kolasa J., Bengtsson J., Gonzalez A., Lowler S.P., Miller T.E., Munguia P., Romanuk T., Schneider D.C., Trzcinski M.K. 2004. Are natural microcosms useful model systems for ecology? // Trends in Ecology and Evolution. Vol.19. P.379384.

Stogov I.A., Movchan E.A., Polyakova N.V., Sukhoparova E.Yu. 1996. [Physico-chemical and biological characteristics of rock pools of Kandalaksha Gulf (White Sea) islands in 1990-1994] // Vestnik SpbGU. Seria 3. Vypusk 2. No.10. P.17-23 [in Russian].

Stogov I.A., Polyakova N.V., Starkov A.I. \& Movchan E.A. 2010. [Plankton invertebrates of White Sea coast water bodies] // Naumov A.D., Alekseev A.P., Sukhotin A.A. (eds.). Problemy izucheniya, ispol'zovaniya i zashchity prirodnykh resursov Belogo Morya. (Materialy XI Vserossiyskoy konferentsii. 911 Noyabrya 2010.). Saint-Petersburg: ZIN RAN. P.179-182 [in Russian].

Tsarev I., Volkova P.A., Glagolev S.M. 2011. Investigation of morphological variability of Daphnia longispina (Cladocera, Crustacea) on Asafii Island (Kandalaksha Gulf, White Sea) using methods of classical and geometric morphometry // Zool. Zhurn. Vol.90. P.109-114 [in Russian, with English summary]

Vekhov N.V. 2001. [Crustaceans of rock pools of Kandalaksha Gulf (White Sea) islands and coasts] // Biologiya Vnutrennikh Vod. No.3. P.20-28 [in Russian].

Responsible editor K.G. Mikhailov

\section{Appendix \\ Приложение}

Appendix Table 1. Frequencies of occurrence of "common" Cladocera species, calculated after sampling of high number of pools on various islands.

Приложение. Таблица 1. Частоты встречаемости «обычных» видов Cladocera на разных островах по результатам массового обследования луж.

\begin{tabular}{|c|c|c|c|c|c|c|c|c|c|c|}
\hline & \multicolumn{5}{|c|}{2007} & \multirow{2}{*}{\begin{tabular}{|c}
2008 \\
$\stackrel{0}{\Sigma}$
\end{tabular}} & \multicolumn{4}{|c|}{2010} \\
\hline & ○ & $\stackrel{\wp}{\mathscr{L}}$ & 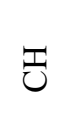 & 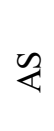 & 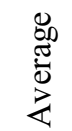 & & ○ & ○ & $\widetilde{J}$ & $\begin{array}{l}8 \\
8 \\
\overline{0} \\
0 \\
2\end{array}$ \\
\hline Daphnia magna & 48 & 83 & 59 & 32 & 56 & 88 & 41 & 78 & 56 & 58 \\
\hline D.pulex & 5 & 4 & 15 & 4 & 7 & 12 & 9 & 16 & 0 & 8 \\
\hline D.longispina & 0 & 0 & 18 & 0 & 5 & 0 & 0 & 0 & 11 & 4 \\
\hline D.curvirostris & 30 & 4 & 12 & 39 & 21 & 0 & 22 & 2 & 0 & 8 \\
\hline Scaphleberis mucronata & 3 & 22 & 27 & 14 & 17 & 47 & 4 & 13 & 29 & 15 \\
\hline Ceriodaphniasp. & 5 & 74 & 41 & 21 & 35 & 47 & 11 & 36 & 31 & 26 \\
\hline Polyphemus pediculus & 0 & 0 & 18 & 0 & 5 & 0 & 0 & 4 & 0 & 1 \\
\hline Bosmina longirostris & 0 & 0 & 21 & 4 & 6 & 0 & 0 & 2 & 16 & 6 \\
\hline Chydorus sphaericus & 50 & 87 & 77 & 93 & 77 & 94 & 57 & 82 & 80 & 73 \\
\hline Pools sampled & 40 & 23 & 34 & 28 & 125 & 17 & 46 & 45 & 45 & 136 \\
\hline
\end{tabular}


Appendix Table 2. Annual frequencies of occurrence of Cladocera species on different groups of islands. Приложение. Таблица 2. Частоты встречаемости видов Cladocera на различных группах островов за разные годы

\begin{tabular}{|c|c|c|c|c|c|c|c|c|c|c|c|c|}
\hline & \multicolumn{4}{|c|}{2003} & \multicolumn{4}{|c|}{2004} & \multicolumn{4}{|c|}{2005} \\
\hline & $\begin{array}{l}0 \\
\infty \\
0 \\
\infty\end{array}$ & $\begin{array}{l}\text { D } \\
+ \\
\text { i } \\
\text { in }\end{array}$ & 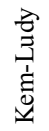 & 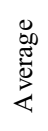 & $\begin{array}{l}0 \\
\infty \\
0 \\
0\end{array}$ & 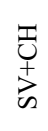 & 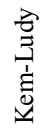 & 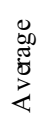 & $\begin{array}{l}0 \\
\infty \\
+ \\
0 \\
\infty\end{array}$ & $\begin{array}{l}\vec{J} \\
+ \\
+ \\
\text { D }\end{array}$ & 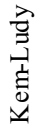 & 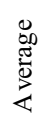 \\
\hline Daphnia magna & 79 & 9 & 44 & 44 & 71 & 9 & 56 & 48 & 64 & 18 & 52 & 46 \\
\hline D.pulex & 43 & 18 & 7 & 18 & 36 & 0 & 4 & 11 & 57 & 9 & 19 & 26 \\
\hline D.longispina & 7 & 27 & 7 & 11 & 0 & 18 & 15 & 11 & 0 & 0 & 4 & 2 \\
\hline D.curvirostris & 0 & 0 & 11 & 6 & 0 & 9 & 4 & 4 & 0 & 9 & 15 & 9 \\
\hline Scaphleberis mucronata & 14 & 27 & 22 & 20 & 21 & 64 & 15 & 26 & 14 & 45 & 11 & 18 \\
\hline Ceriodaphnia sp. & 43 & 9 & 15 & 20 & 50 & 55 & 30 & 39 & 57 & 18 & 26 & 31 \\
\hline Polyphemus pediculus & 0 & 18 & 22 & 15 & 0 & 27 & 7 & 9 & 0 & 18 & 7 & 7 \\
\hline Bosmina longirostris & 7 & 45 & 22 & 22 & 0 & 45 & 22 & 20 & 0 & 45 & 11 & 15 \\
\hline Chydorus sphaericus & 86 & 55 & 48 & 57 & 79 & 45 & 37 & 48 & 71 & 55 & 41 & 50 \\
\hline Pools sampled & 14 & 11 & 27 & 54 & 14 & 11 & 27 & 54 & 14 & 11 & 27 & 54 \\
\hline
\end{tabular}

\begin{tabular}{|c|c|c|c|c|c|c|c|c|c|c|c|c|c|c|c|c|}
\hline & \multicolumn{7}{|c|}{2007} & \multicolumn{4}{|c|}{2008} & \multicolumn{5}{|c|}{ Average } \\
\hline & $\begin{array}{l}0 \\
\infty \\
0 \\
\infty\end{array}$ & $\begin{array}{l}0 \\
\infty \\
+ \\
0 \\
m\end{array}$ & 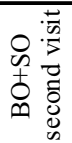 & 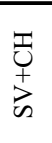 & 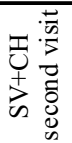 & 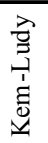 & $\begin{array}{l}\mathscr{8} \\
\mathbb{Z} \\
\mathbb{5} \\
⿱ 亠 乂\end{array}$ & $\begin{array}{l}0 \\
\mathscr{D} \\
0 \\
0 \\
0\end{array}$ & $\begin{array}{l}\vec{J} \\
+ \\
\dot{\Delta}\end{array}$ & 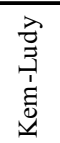 & 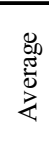 & 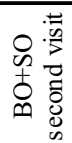 & 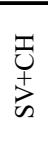 & 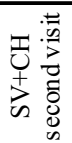 & 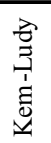 & 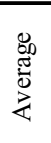 \\
\hline Daphnia magna & 43 & 64 & 50 & 18 & 9 & 44 & 40 & 62 & 14 & 49 & 44 & 64 & 18 & 18 & 48 & 41 \\
\hline D.pulex & 36 & 50 & 25 & 9 & 9 & 15 & 21 & 41 & 8 & 10 & 19 & 43 & 0 & 9 & 3.7 & 17 \\
\hline D.longispina & 0 & 0 & 0 & 27 & 9 & 7 & 8 & 1 & 15 & 10 & 9 & 0 & 18 & 9 & 19 & 10 \\
\hline D.curvirostris & 7.1 & 7 & 8 & 9 & 0 & 7 & 7 & 7 & 4 & 8 & 7 & 29 & 0 & 0 & 3.7 & 8 \\
\hline Scaphleberis mucronata & 43 & 43 & 33 & 45 & 64 & 15 & 35 & 27 & 55 & 17 & 29 & 21 & 64 & 73 & 22 & 39 \\
\hline Ceriodaphniasp. & 57 & 57 & 42 & 45 & 64 & 15 & 39 & 51 & 39 & 21 & 34 & 50 & 55 & 27 & 22 & 39 \\
\hline Polyphemus pediculus & 0 & 0 & 8 & 27 & 27 & 37 & 23 & 1 & 24 & 21 & 15 & 0 & 27 & 27 & 30 & 18 \\
\hline Bosmina longirostris & 0 & 0 & 0 & 45 & 55 & 30 & 25 & 1 & 52 & 21 & 22 & 0 & 64 & 64 & 22 & 26 \\
\hline Chydorus sphaericus & 79 & 79 & 58 & 55 & 73 & 48 & 60 & 78 & 59 & 47 & 58 & 93 & 82 & 45 & 59 & 70 \\
\hline Pools sampled & 14 & 14 & 12 & 11 & 11 & 27 & 75 & 96 & 77 & 135 & 314 & 14 & 11 & 11 & 27 & 77 \\
\hline
\end{tabular}

Appendix Table 3. Comparison of Cladocera occurrence frequencies on different islands using proportion test calculated using data of wide-scale surveys on SO, BO and CH in 2007 and 2010 and data of long term observations of AY in 2003-2008 and wide-scale survey in 2010.

Приложение. Таблица 3. Достоверность различий частот встречаемости Cladocera на разных островах, выявленная с помощью теста пропорций (использованы данные массовых обследований луж на SO, BO и СН за 2007 и 2010 гг., данные многолетних наблюдений луж на AY за 2003-2008 гг. и массового обследования за 2010 г.).

\begin{tabular}{|c|c|c|c|c|c|c|c|c|c|c|c|}
\hline & \multicolumn{5}{|c|}{ Frequencies of occurrence } & \multicolumn{6}{|c|}{ Pairwise is land comparisons (p-values) } \\
\hline & 2 & 己 & $\stackrel{0}{\oplus}$ & ঃ & $\begin{array}{l}0 \\
\infty \\
0 \\
0\end{array}$ & $\begin{array}{l}0 \\
\mathscr{W} \\
1 \\
0 \\
\varnothing\end{array}$ & 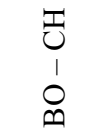 & $\begin{array}{l}\grave{\psi} \\
1 \\
0 \\
0\end{array}$ & $\begin{array}{l}\vec{J} \\
1 \\
0 \\
0\end{array}$ & $\begin{array}{l}\grave{2} \\
1 \\
0 \\
0\end{array}$ & $\begin{array}{l}\vec{J} \\
1 \\
1 \\
2\end{array}$ \\
\hline Daphnia magna & 42 & 57 & 44 & 86 & 62 & 0.0000 & 0.1819 & 0.7160 & 0.0066 & 0.0000 & 0.0451 \\
\hline D.pulex & 8 & 6 & 7 & 13 & 10 & 0.4568 & 0.8841 & 0.9520 & 0.3865 & 0.4786 & 0.9164 \\
\hline D.longispina & 9 & 14 & 0 & 0 & 0 & 0.0000 & 0.0011 & 0.0098 & 0.0039 & 0.0238 & 0.3764 \\
\hline D.curvirostris & 15 & 5 & 26 & 3 & 16 & 0.0003 & 0.0007 & 0.0615 & 0.8178 & 0.0202 & 0.0512 \\
\hline Scaphleberis mucronata & 19 & 28 & 4 & 17 & 9 & 0.0148 & 0.0000 & 0.0017 & 0.1355 & 0.7748 & 0.1696 \\
\hline Ceriodaphniasp. & 22 & 35 & 8 & 53 & 27 & 0.0000 & 0.0000 & 0.0095 & 0.1505 & 0.0002 & 0.0523 \\
\hline Polyphemus pediculus & 20 & 8 & 0 & 3 & 1 & 0.3766 & 0.0287 & 0.0000 & 0.3813 & 0.0025 & 0.0293 \\
\hline Bosmina longirostris & 21 & 18 & 0 & 1 & 1 & 0.9060 & 0.0001 & 0.0000 & 0.0030 & 0.0004 & 0.6840 \\
\hline Chydorus sphaericus & 57 & 79 & 54 & 90 & 69 & 0.0002 & 0.0013 & 0.6661 & 0.5406 & 0.0003 & 0.0026 \\
\hline Pools sampled & 143 & 79 & 86 & 63 & 149 & & & & & & \\
\hline
\end{tabular}


Appendix Table 4. Average frequency of occurrence of "common" cladocerans in pool groups on AS in different years. * _ no data.

Приложение. Таблица 4. Средние частоты встречаемости «обычных» видов Cladocera в разных группах луж на о. Асафий за разные годы наблюдений. * - нет данных.

\begin{tabular}{|c|c|c|c|c|c|c|c|c|c|c|c|c|c|c|c|c|}
\hline & \multicolumn{8}{|c|}{2003} & \multicolumn{8}{|c|}{2004} \\
\hline & $\frac{p}{\frac{1}{0}}$ & $\begin{array}{l}1 \\
1 \\
\infty \\
0 \\
0 \\
0 \\
0\end{array}$ & $\begin{array}{l}\overline{7} \\
\frac{1}{2} \\
\frac{n}{8} \\
0\end{array}$ & $\begin{array}{l}\tilde{1} \\
\frac{\infty}{a} \\
\frac{\infty}{0} \\
\varepsilon\end{array}$ & \begin{tabular}{l}
$n$ \\
ñ \\
\multirow{J}{*}{} \\
$\frac{n}{8}$ \\
8 \\
0
\end{tabular} & $\begin{array}{l}\stackrel{2}{N} \\
\text { do } \\
\frac{n}{8} \\
8 \\
0\end{array}$ & $\begin{array}{l}m \\
1 \\
0 \\
m \\
\infty \\
0 \\
8 \\
\varepsilon\end{array}$ & 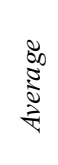 & $\frac{1}{\frac{1}{8}}$ & $\begin{array}{l}\simeq \\
\infty \\
\infty \\
0 \\
\varrho\end{array}$ & $\begin{array}{l}\bar{T} \\
n \\
n \\
\frac{n}{8} \\
2\end{array}$ & $\begin{array}{l}\stackrel{\infty}{N} \\
\infty \\
\frac{n}{0} \\
0 \\
0\end{array}$ & \begin{tabular}{l}
$n$ \\
ñ \\
\multirow{2}{N}{} \\
$\frac{n}{8}$ \\
8 \\
0
\end{tabular} & $\begin{array}{l}\text { શे } \\
\text { dे } \\
\text { on } \\
\frac{0}{8}\end{array}$ & $\begin{array}{l}m \\
\hat{p} \\
0 \\
n \\
0 \\
\delta \\
0\end{array}$ & $\begin{array}{l}8 \\
8 \\
5 \\
0 \\
0 \\
3\end{array}$ \\
\hline Daphnia magna & & & & & & & & 25 & & & & & $*$ & & & 35 \\
\hline D.pulex & & & & & & & & 5 & & & & & $*$ & & & 0 \\
\hline D.longispina & & & & & & & & 6 & & & & & $*$ & & & 14 \\
\hline D.curvirostris & & & & & & & & 5 & & & & & $*$ & & & 2 \\
\hline Scaphleberis mucronata & & & & & & & & 16 & & & & & $*$ & & & 16 \\
\hline Ceriodaphnia sp. & & & & & & & & 12 & & & & & $*$ & & & 15 \\
\hline Polyphemus pediculus & & & & & & & & 16 & & & & & $*$ & & & 9 \\
\hline Bosmin a longirostris & & & & & & & & 16 & & & & & $*$ & & & 14 \\
\hline \multirow[t]{2}{*}{ Chydorus sphaericus } & & & & & & & & 52 & & & & & * & & & 28 \\
\hline & \multicolumn{8}{|c|}{2005} & \multicolumn{8}{|c|}{2007} \\
\hline Daphnia magna & & & & & & & & 39 & & & & & & & & 34 \\
\hline D.pulex & & & & & & & & 11 & & & & & & & & 3 \\
\hline D.longispina & & & & & & & & 6 & & & & & & & & 18 \\
\hline D.curvirostris & & & & & & & & 13 & & & & & & & & 2 \\
\hline Scaphleberis mucronata & & & & & & & & 10 & & & & & & & & 21 \\
\hline Ceriodaphnia $\mathrm{sp}$. & & & & & & & & 19 & & & & & & & & 22 \\
\hline Polyphemus pediculus & & & & & & & & 5 & & & & & & & & 30 \\
\hline Bosmina longirostris & & & & & & & & 10 & & & & & & & & 18 \\
\hline \multirow[t]{2}{*}{ Chydorus sphaericus } & & & & & & & & 54 & & & & & & & & 76 \\
\hline & \multicolumn{8}{|c|}{2008} & & \multicolumn{5}{|c|}{ Average for all years } & & \\
\hline Daphniamagna & & & & & $*$ & & & 31 & & & & & & & & 33 \\
\hline D.pulex & & & & & $*$ & & & 8 & & & & & & & & 5 \\
\hline D.longispina & & & & & $*$ & & & 10 & & & & & & & & 11 \\
\hline D.curvirostris & & & & & $*$ & & & 5 & & & & & & & & 6 \\
\hline Scaphleberis mucronata & & & & & $*$ & & & 12 & & & & & & & & 15 \\
\hline Ceriodaphnia $\mathrm{sp}$. & & & & & $*$ & & & 17 & & & & & & & & 17 \\
\hline Polyphemus pediculus & & & & & $*$ & & & 31 & & & & & & & & 18 \\
\hline Bosmina longirostris & & & & & $*$ & & & 26 & & & & & & & & 17 \\
\hline \multirow[t]{2}{*}{ Chydorus sphaericus } & & & & & $*$ & & & 31 & & & & & & & & 54 \\
\hline & & $0 \%$ & & & \multicolumn{2}{|c|}{$1-33 \%$} & & \multicolumn{2}{|c|}{$34-65 \%$} & & \multicolumn{3}{|c|}{$66-100 \%$} & & & \\
\hline
\end{tabular}

